\title{
Intellectuals and Resentment Toward Capitalism
}

\author{
Thomas Cushman
}

Published online: 13 March 2012

(C) Springer Science+Business Media, LLC 2012

This article revisits a central "thought-style", to use Karl Mannheim's term, among intellectuals: resentment toward capitalism. A generalized hostility to capitalism has taken many forms in industrial modernity. Marx was the idealtypical resentful intellectual, whose visceral hatred of capitalism was a constant presence in his supposedly scientific historical materialism. The rise of socialism in 18th and 19th century Europe and global communist totalitarianism in the 20th century were fundamentally driven by intellectuals who were marginal to capitalism and who transformed their hatred of it into a class war against the bourgeoisie. In its most extreme forms, bitter and resentful intellectuals aimed to redress a diffused sense of social and economic injustice through murder and mayhem against capitalists; where real "enemies of the people" did not exist they were created in a simplistic cosmology in which the capitalist system and capitalist classes were seen as the most demonic forces of evil.

During the crises that wracked capitalism in Western democracies in early 20th century, radical intellectuals waged a sustained campaign of class warfare grounded in an essentialist conception of capitalism and capitalists that became increasingly ingrained in more mainstream political culture throughout the 20th century. The 1960s was fueled by anti-systemic thinking in which capitalism, a la Herbert Marcuse, was constructed as a greater threat than Soviet imperialism. In the early 21 st century, we have seen the demagogic manipulation of class resentment by President Barack Obama and legislators, whose power depends on the continued existence of an inert and unproductive entitlement

T. Cushman $(\bowtie)$

Department of Sociology, Wellesley College,

Wellesley, MA 02481, USA

e-mail: tcushman@wellesley.edu class of voters who survive on the forced transfer of property from the productive classes. Among intellectuals on the left, the dissolution of the communism in the late 20th century, became a pretext for a new, invigorated rhetoric of anti-capitalism, grounded in the reified conception of "neo-liberalism", a new worldwide evil that, for many anti-capitalists, fulfills the Marxist prophecy of the juggernaut which destroys everything in its path and melts all that is solid into air.

The decline of the independent public intellectual in the 20 th century pushed Western leftist intellectuals into capitalist-funded institutions of higher education. Rather than an overt process of what Julian Benda referred to as le trahison des clercs, in which intellectuals actively embraced pernicious nationalisms, modern intellectuals have been mainly conglomerated into academic institutions by forces of bureaucratic rationalization. Within such comfortable sinecures, their public influence has waned and their primary concern has been their consolidation as a status group with its own cultural system of beliefs, values, and ideologies. Distant from the rough and tumble of the market, intellectuals have articulated a cultural critique of capitalism that serves as a kind of cultural capital that is, ironically, the very source of their own privileged socio-economic status as elites. In the social sciences (with the exception of economics, in which resistance to capitalism is mainly found in persistent adherence to the godhead of liberal Keynsianism) and the humanities, some degree of hostility to capitalism is a necessary disposition for success in the academic world, regardless of one's substantive areas of expertise. In 2001, the well-known literary journal, Semiotext(e), published a quarter century of its "best" articles including famous French theorists such as Gilles DeLeuze and Jean Baudrillard, the American feminist Kate Millet, and the German terrorist, Ulricke Meinhof. The title of the volume was Hatred of Capitalism, presumably 
because it captured the authors' fundamental, emotional, orienting principle to the world.

The general picture in much of academia is one of an entire class of intellectuals whose very existence is supported by the very capitalist system, which, to varying degrees, they resent. This contradiction - the capitalist support of the anti-capitalist critique - cannot be made visible in opposition to the dominant orthodoxies of the new intellectual class. It is threatening to the very core of this modern status group. Contradictions exposed are legitimation crises and those who expose them must be marginalized, neutralized, and nihilated, in Peter Berger and Thomas Luckmann's sense. Support of capitalism from within the discursive world of anti-capitalists is painted as "unnatural", "crazy", or "dangerous".

There is no necessary connection between intellectuals and resentment of capitalism. In general, though, it would be fair to say that some degree of hostility toward capitalism would be precondition for claiming the identity and status of "intellectual" these days. This is in contrast to the libertarian intellectuals who founded the American republic, who were expansive and polymathic thinkers who saw capitalist enterprise as the foundation of individual freedom, human rights, and democracy. The trajectory of what might be called "sedimented anti-capitalism"- the taken-for-granted reality that any "right-thinking" intellectual's position must inherently be founded on an anti-capitalist sentiment of some form or another - emerged out of the trajectory of capitalist modernity. There are good empirical reasons why this should have happened, given the rapacious nature of capitalism described so well by Marx, Engels, and their intellectual heirs. One cannot deny the pathologies of capitalism and, given that the rise of capitalism had not yet produced an enfranchised middle class or an intellectual class that could sustain itself by thinking for money, it is understandable that strident critiques of capitalism emerged as part of the development of capitalism itself.

Since Marx and the successive intrusion of Marxian thought into all sectors of intellectual life, capitalism has always been reduced to its worst qualities. The anticapitalist thought structures of the intellectual classes went beyond the more balanced sociological critiques of capitalism that were inherent to much theorizing about the consequences of capitalist modernity. In Economy and Society, when Weber described "the market", as an "abomination (Abscheu) against all systems of fraternal ethics", he did so without intending to essentialize the market as a demonic force to be eradicated. His was a scientific analysis of the tension between instrumental rationality and substantive values. For Weber, rationalization processes had both positive and negative outcomes. Similarly, Simmel's view of capitalism in The Philosophy of Money made the ironic outcomes of capitalism central to his theory of modernity: money freed people from the bonds of tradition (what he termed "negative freedom"), but also created a system of constant challenges to individual subjectivities and exacerbated objective social conflicts. As anti-capitalism became a sedimented style of thought, it moved further away from the ironic mode of theorizing that was so central to powerful classical theories of capitalism. This sedimentation entailed a fundamental "de-sophistication" of more complex theories of capitalism, which, in its most basic forms, elided the positive elements of capitalism and amplified its negative ones. Over time, knowledge about capitalism has become thoroughly soaked with ideology and cloaked in the various jargons of respectable disciplines in the social sciences and the humanities.

Anti-capitalism has become, in some ways, a central pillar of the secular religion of the intellectuals, the habitus of modern critical intellectuals as a status group. The term "critical intellectuals" does not refer only to those on the left, though it is generally understood this way. Anticapitalism is also to be found on the right, for instance, in the anti-technological writings of thinkers such as Arnold Gehlen and Martin Heidegger and literary figures such as T. S. Eliot and Ezra Pound. Nonetheless, this earlier form of critique has given way to the predomination of left-wing critiques of capitalism, which are central to nearly all those who claim the status of intellectual, especially in the social sciences and humanities. Edward Said's idea that the intellectual is defined primarily by "speaking truth to power" entails a fundamental commitment to anti-capitalism, either in its earlier forms of "imperialism" or its newer form of globalized "neoliberalism." Anti-capitalism manifests itself along a continuum from "soft" liberal welfare statism to "hard" radical Marxian-anarchist critiques. As a thoughtstyle, it is evident in some academic disciplines more than others. Supporters and proponents of capitalism exist in contemporary academic intellectual fields, but always as marginal, barracked in pragmatic quarters such as technological institutes, business schools or right-of-center think tanks.

Why do intellectuals resent capitalism? It is not intuitive that they should: in fact one might expect that intellectuals would be wise enough to recognize that it is only as a result of the excess productivity and surplus of capitalism that it is possible for something like an intellectual class to develop more generally. To be an intellectual is to pursue a form of self-actualization and subjectivity that can only be realized on a large scale in a market society. The critical reflexivity and impulse to see complexity in the world evaporate in anti-capitalist intellectuals when they confront the reality of capitalism. The abstracting subjectivity of the intellectual is supported by the concrete objectivity of capital. At the start of any inquiry into intellectual hostility toward capitalism, it is important to stress this fundamental irony: intellectuals are inextricably linked to capitalism, yet are hostile to it, and 
thus live in a state of fundamental existential tension and contradiction. Their subjectivities are at odds with the objective realities of their lives; they are estranged and alienated from the very structures that make their existence possible. As such, these connections must be actively masked, and any thoughts that make them visible must be "neutralized" or "nihilated." The prototypical case in this regard was Karl Mannheim, who was subjected to harsh critique and ideological nihilation for (very creatively and ironically) using Marxian arguments to expose the class bases of intellectuals and their ideological and utopian styles of thought. Mannheim, the critical and progressive intellectual, was redescribed as "right-wing" and "reactionary" for using the master's conceptual tools to dismantle the master's ideological house. These terms continue to be used as rhetorical weapons to destroy any dissent from left-wing orthodoxies or defense of free-market social systems.

The resentment of intellectuals toward capitalism is something that needs to be explained, especially in the present day when virtually all intellectual labor for its own sake is subsidized by surplus wealth produced by capitalist production. There is much to be gained by considering anticapitalism to be a specific kind of resentment. Resentment is a particular kind of emotion, in which the object toward which resentment is directed, though specified as something that is undesirable is, in fact, perhaps desired, yet unobtainable. The literary critic and anthropologist Eric Gans sees resentment as necessarily involving a sense of victimage, as a kind of revolt against a centrality that excludes the person who resents. Resentment is a complex feeling, and one for which there is, at best, only a nascent sociology. It is to be differentiated from similar emotions with like consequences, such as envy, jealousy, or anger, though it may appear in conjunction it the latter. Envy can be alleviated by providing someone with the desired or envied object; anger is more episodic and emotional and is difficult to sustain within rational epistemologies and world-views; jealousy may be present even when one has an object of desire, but feels as if he does not. Resentment is an existential state that is more intractable, since, in general, the provision of the desired good does not necessarily alleviate it (otherwise it ceases to be resentment). Resentment is particularly intense when the desired good is highly visible, but cannot be had. High status intellectuals resent other high status intellectuals, sometimes in the most acrimonious ways, and the more status they receive the more intense their resentment of others. There is only so much status to go around. The old resent the young because they cannot ever be young again. Women in patriarchal societies resent men because they can never be men.

Intellectuals resent capitalism because they do not have the "right" kinds of knowledge to succeed in the capitalist system of acquisition. Also, because if their "useless knowledge", they are marginalized from it in spite of their superior intellectual qualities, skills, or accomplishments. Intellectuals enjoy a most unique kind of freedom in modernity - the freedom to think without regard for practical outcome - yet they often live in a state of resentment against the system that affords them this freedom. This resentment entails a sense of victimage, even while those who feel such victimage are, objectively, superordinate both economically and culturally in the social hierarchies of the market societies in which they live. And this sense of resentment often fuels social action against the market system, most often through acceptance of redistributive policies that are justified by the sedimented, essentialized, negative social constructions of capitalism. Contemporary intellectuals have long since abdicated the role of revolutionaries: the true revolutionary intellectuals devoured each other in the conflagrations of the last century and have given way now to a bureaucratized class of thinkers who, more often than not, cannot see any real practical economic or political outcomes of their thinking and, as I discuss below, are bothered by this fact.

The starting point is from the sociology of knowledge and intellectuals, which means suspending the idea there is something ontologically "real" about the qualities of capitalism. From this perspective, anti-capitalist critiques are seen as a product of the particular existential conditions and experiences of anti-capitalist intellectuals within capitalist society itself. This is a rather uncommon theoretical move, since most intellectuals, being hostile to capitalism, would not conceive that this hostility itself could be unit of analysis. Their critical capacities are reserved for capitalism itself, rather than knowledge about capitalism and the ideological dimensions of such knowledge. They do not exhibit the reflexivity necessary to understand knowledge about capitalism as a "product" rather than something that is, sui generis, real (and always negative). Sedimented realities resist reflexivity even among the most highly reflexive.

I would like to illuminate this issue of intellectual resentment toward capitalism through the work of two thinkers who addressed intellectual resentment and hostility of capitalism by intellectuals as a phenomenon in its own right and worthy of analysis: the philosopher Robert Nozick, and the sociologist/philosopher Lewis S. Feuer. Their work represents just two approaches to a more general, but inchoate sociology of anti-capitalism. They grasped the fundamental reality of anti-capitalist thought-styles as social products and as dispositions of intellectuals gained from their social positions, experiences and their phenomenological life-worlds. A more sustained analysis of anti-capitalist thought styles would involve unpacking these cultural meanings and myths from the stocks of knowledge that see themselves as merely objective renderings of the capitalist system as such. 


\section{Irrational Sources of Hostility to Capitalism}

Lewis Feuer was deeply interested in the ways in which the emotional states of intellectuals influenced their intellectual work. His work on the scientific intellectual, as well as on Marx and the Marxists, explored the curious antinomies between rational, and irrational forces. He was particularly interested in looking at the irrational, or emotive, bases of what purported to be the most scientific and rational thought systems. In his book, Einstein and the Generations of Science (1974), his sociological analysis, for instance, of Einstein's scientific work drew strong correlations, or what he called "isoemotional lines", between the radicalism of that work and Einstein's association with emotionally driven radicals in Zurich. Feuer's work has often been seen as excessively psychological and reductionistic, and the influence of psychoanalysis on his work is unmistakable. Feuer clearly saw subjectivity as fundamentally linked to social and cultural structures and his psychoanalytic interpretations were his major avenue for exploring the more general sociological issue of irrationality. At times, his reliance on psychoanalytic reasoning was excessive, yet the idea of linking rational intellectual productivity to unconscious irrational motives and emotions was unique and often powerful.

Feuer had been a leading intellectual of the 1930s left in the United States, and a major scholar and interpreter of Marx and Marxisms. His sociology of Marxism avoided the fellow-travelling of similar efforts by scholars such as Alvin Gouldner. Like many of his contemporaries, he was disillusioned with the failed Soviet experiment in socialism and increasingly moved to a strong conservative position, which was intensified by his close observations of and involvement in the student movements of the 1960s at the University of California in Berkeley (which resulted in a book The Conflict of Generations: On the Character and Significance of Student Movements [1969]). Feuer established a pattern of providing intense analytical scrutiny of movements of which he once been had been a part, using his own experiences and observations as ethnographic data. This also made him not just a critic of left-wing, radical movements, but an apostate who earned the scorn of the left intellectuals. His willingness as a professor to to expose the irrationality of the student movements and to stand up to puerile student demands and the obsequious kowtowing of radical professors led to his resignation as a full professor of philosophy from Berkeley.

Feuer's views on intellectuals and capitalism run throughout his work, but are elaborated in a rather obscure essay that was presented at a conference on anti-capitalism and published subsequently in a collection published 1979 and entitled Capitalism: Sources of Hostility, edited by Earnest van den Haag (who, like Feuer, had turned away from his early radicalism and sought to explain it as a social phenomenon). Feuer's main task in the essay was to understand what he termed "irrational forces of opposition to the market system." Perhaps too psychoanalytically for some, he sees irrational sources of objection to the market as "founded on largely repressed or unconscious feelings which contravene the person's basic conscious values." Feuer was inspired in this by the model of Marx's antinomian personality: the great thinker who inspired collective workers' revolutions but eschewed participation in party politics, drew sustenance from his capitalist friend Engels, and expressed a disdain for common workers. What interested Feuer were how the supposedly rational thinking of intellectuals was fundamentally influenced and prefigured by a priori socially and cultural mediated irrational forces, and how these irrational forces were overtly denied and repressed by the intellectuals themselves and their followers.

For Feuer, intellectuals are "unnatural", in the sense that their thinking is most often not connected to any action or practical outcomes. Intellectuals think, but their thinking is not doing, in the sense of pragmatic and discernible outcomes such as the production of things of material value. The value of intellectual work, in its ideal typical sense, is cultural and intellectuals are rewarded for producing knowledge, which even in its most applied forms, is still symbolic rather than practical activity. As cultural capital, then, knowledge is valuable in and of itself precisely because it is not practical, or if it is the practicality of it is masked. This is the case in economics, for instance, where students receive degrees in the field, which have symbolic value, but are not specifically referred to as vocational training (indeed, to say that a degree in economics from a liberal arts college is a credential of purely practical value, or some kind of vocational training, would be an insult). So, in the first instance, intellectuals would be disposed to be hostile toward capitalism because they see it as entirely practical, and construct this practicality as devoid of conceptual or moral substance and value.

Following in a tradition of the analysis of personality types in sociological theory, Feuer describes the "dialectical personality of our time". The dialectical personality, for Feuer, was represented in crystalline form in the work of earlier thinkers such as Karl Marx, George Bernard Shaw, and Thorstein Veblen; in his own contemporaries, Herbert Marcuse, Erich Fromm, and Paul Goodman; and in a collective form in the student radicals and their acolyte professors in the 1960s. "The dialectical personality is moved by a compulsive spirit of contrariety; he wishes, in a Marxist metaphor, to stand things on their head... the system must be inexorably 'negated'; negation is indeed endowed by such writers with a special emotional valence." This dialectical personality was strongest in the attack on and negation of the free market societies in which these intellectuals lived. These dialectical personality types, for Feuer, "regarded entry into the competitive market as a traumatic and degrading 
experience" and so strong were these feelings that it led leftist intellectuals to support all forms of state power as a remedy to control the juggernaut of capitalism. The most horrifying consequences of this position were evident in the state sponsored totalitarian experiments of the 20th century and in lighter forms such as the left-liberal social democratic impulse to empower the state in all spheres of social life, without regard for classical individual rights.

Feuer offers the example of the leftist critique of "monopoly capitalism waging war against the environment" and notes, very presciently at the time, the connection of environmental movements with new age spirituality and other forms of re-enchanting irrationality. The 1960s critique of the war against the environment provided the seeds of the environmental movements of the early 21 st century, in particular the war against climate change and global warming. While the issue of climate change is a complex one, the central argument of the campaign against global warming is that it is caused by anthropogenic, or man-made forces. These forces are industrial, and attributed primarily to capitalism. Feuer notes that the record of environmental catastrophe produced by Soviet industrialism was always rendered invisible in preference to attributing industrial evil to capitalism in Western democracies alone. Such cognitive maskings themselves become objects of sociological analysis.

While modern environmental movements do not always specifically cite the arguments of anti-capitalists such as Marcuse and Fromm, their structures of thinking are remarkably homologous with those of this earlier generation of anti-capitalists. It is unregulated capitalism that is the source of the coming climactic apocalypse and the response has been toward intense regulation, not from within capitalism itself - say, through competitive market mechanisms that reward green innovation and consumer satisfaction-but from the state. Anti-capitalism is always associated with a push toward the intensification of the power of the state and any negative effects from the latter in terms of the abridgments of negative freedoms and individual rights is unaddressed, or consciously repressed. This is the most fundamental reality of anti-capitalism as a movement from its earliest origins, say in 17th century France to the modern day: it is always in movement against the upper classes with the intensified power of the state as its main instrument of coercion.

The modern environmental movement, and its intellectual arm in academia, what has come to be called "Environmental Studies", has revivified structures of anti-capitalist thinking. And while students no longer worship so much at the altar of Marx and Marcuse, the sustainability movement is a new form of bureaucratic compulsion, grounded in a fundamentalist belief that capitalist industrial society is the motor force of the coming climactic apocalypse. The environmental movement of the early 21 st century depends on a phalanx of intellectuals who produce scientific knowledge in defense of the thesis of global warming, who consider this knowledge as "settled science," and who ward off attacks by the supposedly anti-scientific global warming skeptics by equating them with forces of irrationality and anti-science. Quite respectable scientists (among them several Nobel laureates) who want to explore scientifically alternative hypotheses regarding climate change, and economists who want to question whether a new regulatory monolith should be created as opposed to market forces, can quite easily be grouped with anti-scientific religious fanatics and easily dismissed. Also, those who refuse to entertain scientific challenges to anthropogenic theories, and who imagine their thesis as the "most" scientific position, directly refuse to accept the foundational epistemological basis of science: the falsifiability of findings. Of course, once science has decided that something is "certain", it ceases to be science and what the response to critics of the global warming movement shows in its purest form is the social control of the most fundamental of scientific activities, in this case, any effort at all toward falsification of the regnant orthodoxies.

Falsifiers, who in ordinary science ought to be welcomed as the dialectical force, which drives advances in knowledge, are redescribed by ideological anti-capitalists as irrational and misguided, and are metaphorically described as "flat earthers" or "deniers". Scientific skeptics are epistemologically annihilated. All of this takes place simultaneously with the rejection of reflexivity necessary to understand the a priori social and cultural forces that shape knowledge production in the scientific fields of climate change, in this case the anti-systemic generational dispositions of the anticapitalist intellectuals. The contemporary environmentalist movement embodies a deep hostility and resentment toward capitalism, is willing to unleash virtually any form of state regulatory power against it, and denies that there can be alternative or skeptical ideas or solutions. The dialectical personality type in this case counters all external realities but rigidly blocks, neutralizes, and annihilates any dialectical challenge to its own though structures, knowledge, and ideological positions. For Feuer, "the emotional a priori or postulate of the dialectical personality is that whatever the social problem, no solution shall be possible within the capitalist system." Feuer's conception describes the idealtypical anti-capitalist intellectual, and the more common type of dialectical personality of our time is one who thinks that no matter what the capitalist enterprise, it needs to be painstakingly regulated by state power. And in cases where capitalism is to be promoted, it is to be done so in relation to a "green" ideological agenda, even if this results in fantastic boondoggles such as the Obama administration support of the failed solar energy company Solyndra.

Feuer was writing primarily about the enduring legacy of the anti-capitalism of the 1960s generation, but a major question is how the dispositions of these generations have 
persisted in modern intellectual life, especially in the modern academy. In the modern context, anti-capitalist thinking has been conjoined with the ideology of multiculturalism, which accepts capitalism as problematic, but links it with other forms of "domination" based on race, ethnicity and gender. That class domination is a central focus of the modern academic intellectual is expected given the fact that the most powerful leaders within the status group of such intellectuals were product of the 1960s. The then inchoate feminist and black power movements of the 1960s have dispersed more widely throughout the academy and, though sounding quite revolutionary, are quite disconnected from radical social change. Present-day movements for diversity, though deploying the rhetoric of war against white, upper class, male hegemons, are, at base, movements for the class and status aggrandizement of a broad range of supposedly "marginalized" peoples and "victim" groups. Just as overt anti-capitalism has and continues to be the cultural capital of intellectual classes, diversity is now a form of capital that is an entry ticket to higher socio-economic status. What is required now, politically, is the alignment of the newly empowered with the central redistributive agenda of the welfare state, which, at its very core focuses on providing resources to the "disempowered" at the expense of the most productive classes.

As with anti-capitalism, the ideology of multiculturalism must always mask its role as a technique of insertion into the capitalist system itself. The diversity movement is fundamentally about replacing certain types of people in the social hierarchy with other types of people; the basis for this "reinsertion" is phylogenetically determined, so much so that phylogeny has now become a de facto measure of cultural difference. In the new regime of diversity, there can never be enough diversity in social and cultural life, just as in previous eras there could never be enough rich, powerful white men dominating in all spheres of social life. There can never be an end point at which it is said: "We have achieved a remarkable measure of diversity and now we can return to the traditional forms of meritocracy." What has happened in the contemporary multicultural world is the instantiation of diversity as an endlessly receding goal, which can never be reached and therefore must be always pursued. Diversity is a pure growth mode ideology (with some notable occurrences: one discovers recently that the Columbia English Department, which is dominated by diverse, post-colonial literary theorists, of the granting of tenure to a white man of European origin on the grounds of "diversity", though one can be assured that the candidate deploys all the correct theoretical vocabularies of the "subaltern").

\section{The Opposition of Intellectuals to Capitalism}

Robert Nozick, one of the foremost philosophers of his generation, gained notoriety as a libertarian-anarchist philosopher in the midst of a sea of Marxian left-wing and Rawlsian liberal intellectuals. His book, Anarchy, State, and Utopia (1974), presented an unflinching critique of radical and liberal philosophies of revolutionary and legislative redistribution and systemic degradation of individual rights. Unlike Feuer, whose critique of the left focused on irrational forces, Nozick's critique was grounded in a rights argument. Nozick challenged the most sacred principles of radicalism and liberalism, arguing in Lockean fashion that the right of individuals to their own bodies and products of labor were non-derogable. His anarchistic position was that the forced transfer of property by other people, states or institutions, except under very limited conditions, was an unjustifiable and fundamental violation of human rights.

Like Feuer, Nozick was marginalized within contemporary academic settings, though Nozick was afforded much more respect by fellow intellectuals and was a distinguished professor of philosophy at Harvard. One wonders, in the orthodox ideological environment of academia, how Nozick's defenses of capitalism and individual rights could have been tolerated by fellow academics. One possibility is that it was a case of "repressive tolerance," in Marcuse's terms, in which Nozick's radical dissent from regnant leftist and liberal orthodoxies was offered as "evidence" of intellectual pluralism. Like Feuer, Nozick offered his own sociology of intellectuals, perhaps as a way to understand his left-liberal colleagues' disdain for his own procapitalist views. It is always fascinating to speculate on the the autobiographical motives for the sociology of knowledge: in this case, both Feuer and Nozick were not only offering original sociological and philosophical arguments, but also seeking to understand the social foundations of the latter.

Nozick's sociology of knowledge and intellectuals appears in a short essay entitled "Why Intellectuals Oppose Capitalism." (this article can be accessed at: http://www. cato.org/pubs/policy_report/cpr-20n1-1.html). Nozick defines intellectuals as "wordsmiths... who, in their vocation, deal with ideas as expressed in words, shaping the word flow others receive. These wordsmiths include poets, novelists, literary critics, newspaper and magazine journalists, and many professors." He excludes artists and most scientists, which is a point of contention. Nozick rightly argues that intellectuals are mainly on the left. He finds it odd that so many intellectuals should oppose capitalism, since others of similar socioeconomic status do not. $\mathrm{He}$ considers that the positions of these intellectuals, in relation to the latter, are anomalous and in need of explanation. One gets the sense that Nozick wanted to know about hostility toward capitalism as a way of understanding the hostile reception to his own anarcho-libertarian ideas.

Nozick offers two types of explanation for hostility toward capitalism, but focuses on one in particular, the 
unique factors that push intellectuals toward anticapitalism. In some ways, he is quite like Feuer in looking for the a priori dispositions that drive antisystemic thought. His theory has to do with the perceived value of intellectuals in their own minds and in terms of their objective socioeconomic status. Possessed of advanced knowledge, intellectuals feel themselves "entitled to the highest rewards their society has to offer and resentful when they do not receive this." He notes that intellectuals ordinarily mingle with successful capitalists, whose success is based on practical knowledge and skills. This propinquity, coupled with a perceived recognition of the lesser intellectual skills of most capitalists, only serves to increase the resentment of the intellectuals to capitalism.

For Nozick, market societies reward those who supply the demands of others in the most efficient way. While he does not draw on Weber, Nozick is basically arguing that it is instrumental rationality that is rewarded, rather than substantive values, which in the case of intellectuals are their own intellectual capabilities and ideas for their own sake. Intellectual status groups are based almost entirely on the construction of the substantive value of ideas (and as noted above, in this case, even anti-capitalist ideas are expected to be somehow valuable in the market society). Communities of intellectuals imagine that rewards ought to be determined by the value of their ideas. To some extent-and Nozick does not mention this-academic intellectuals do link the value of their ideas directly with market value, as evidenced in the widespread practice among them of testing the demand for their ideas in the academic marketplace. The search for the so-called "outside offer" is, to some extent, the way in which the academic intellectual seeks material reward in the market society. But she can only do so by masking this fact and, instead, constructing the search for upward mobility purely as a status game in which knowledge itself is the object of reward. In these calculated efforts to achieve more remuneration for ideas, academic intellectuals must always believe that their ideas are, in and of themselves, the source of value in an institution and can never state the obvious: that the ability of others to reward them for their ideas is itself a quest for socioeconomic status within capitalism. Aspirational and acquisitive intellectuals seek a place within the capitalist hierarchy, which they resent, through the chimerical ruse of attributing ontological value to their ideas as things of worth in-and-of-themselves. Any insinuation that they are "in it for the money" is to be resisted at all costs, because such crass materialist concerns would deny the contrived distance that all intellectuals must maintain as the condition of their membership in the status group of intellectuals, who by their very nature must dialectically reject systems, especially capitalist ones.
Thus, intellectual participation in capitalism must proceed in a roundabout way, in which any insinuation of the market value of their cultural capital must be rendered invisible. There is a further irony here, which Nozick addresses: while most intellectuals support redistributive policies according to a straight-up calculation of need, when it comes to the value of their own "labor", they have an overwhelming sense they should be remunerated because of the value of what they do. Nozick argues that this sense of intellectual superiority is derived from the fact that the intellectuals, in school, are always the most rewarded with high grades, honors, admissions to the best universities, and then are severely disappointed when, all of a sudden, the market system not only fails to remunerate them, but also rewards the non-intellectuals. Nozick writes: "The intellectual wants the whole society to be a school writ large, to be like the environment where he did so well and was so well appreciated. By incorporating standards of reward that are different from the wider society, the schools guarantee that some will experience downward mobility later. Those at the top of the school's hierarchy will feel entitled to a top position, not only in that micro-society, but in the wider one, a society whose system they will resent when it fails to treat them according to their self-prescribed wants and entitlements."

Nozick argues, as well, that intellectuals are rewarded in school by central authorities such as teachers, and avoid the more cacophonous and non-intellectual students who have their own status groups based on non-intellectual criteria and competition, much like in the capitalist system. Intellectuals become dependent on centralized power for their own sense of self-affirmation, which is ironic given the rebellious nature of their subjectivity. This might explain why left-wing intellectuals are so favorably disposed to seek solutions in and even sacralize state power and centralized planning, since they are so obsequious to centralized power in their own localized academic environments. Intellectuals, in spite of their supposed dialectical temperaments, are remarkably conformist. Their success is, more often than not, predicated on doing what they are told, reproducing existing thought structures, getting an "A" on the exam, and passing along the knowledge of others that they themselves have mastered (I leave for another essay the issue of the sado-masochistic tendencies inherent in such a pattern).

In capitalist society, entrepreneurial risk-taking and nonconformity are rewarded and in this respect the intellectual is decidedly disadvantaged, since the number of "paradigm breakers" and "revolutionaries" in intellectual status groups is severely limited. Radical intellectuals celebrate radicals, but very few of them are really radicals themselves, either in their thinking or in their personal lives; the principal habitus of the academic intellectual is a rather stark conformity. The continuance of the intellectual life beyond the school almost always entails a distancing from capitalism, and thus the 
intellectual, while imagining himself as destined for greatness by virtue of superior performance, is actually destined for the opposite track of downward mobility and the resentment that this entails (this is especially the case when the academic intellectual works for a modest salary at an academic institution which is opulent, well-endowed, and run by boards of trustees whose members are chosen almost exclusively from the world of successful capitalists).

Nozick states his sociological theory of intellectual opposition to capitalism in very succinct form: "In a society where one extra-familial system or institution, the first young people enter, distributes rewards, those who do the very best therein will tend to internalize the norms of this institution and expect the wider society to operate in accordance with these norms; they will feel entitled to distributive shares in accordance with these norms or (at least) to a relative position equal to the one these norms would yield. Moreover, those constituting the upper class within the hierarchy of this first extra-familial institution who then experience (or foresee experiencing) movement to a lower relative position in the wider society will, because of their feeling of frustrated entitlement, tend to oppose the wider social system and feel animus toward its norms."

In addition to this hypothesis, Nozick also argues that "schools will tend to produce such anti-capitalist attitudes the more they are attended by a diversity of people." He is primarily speaking of class diversity, in recognition of the fact that open societies provide more opportunity for the comingling and propinquity of people and therefore bring about more mixing of social classes. Within this environment, intellectuals are able to see more clearly the rewarding of non-intellectual pursuits, as for instance, when the student with the brightest future in a high-school is a boy who develops a rap music repertoire based on the vernacular and life-style of the black underclass, or the son of the rich car dealer secures a high paying job right out of school, with all the usual accouterments of higher status.

Nozick does not mention diversity in the modern multiculturalist sense of the concept, yet one might imagine the resentments that increases in diversity might create. Achieving diversity has entailed a relaxation of admission criteria for those who have been traditionally underrepresented in higher educational institutions. This fact is seldom talked about openly, but it is a fact. For most people, but not usually for intellectuals, the primary value of an educational credential is its exchange value in the market society. So, the feelings of intellectual estrangement that are already built into the intellectual's structural impediments to mobility are exacerbated by the recognition that lesser qualified individuals - even more so than usual - are advancing further in terms of recognition in capitalist society. Such a subjective feeling would be very difficult to excavate ethnographically, but one can logically deduce the exacerbations of resentments by programs of diversity and affirmative action. Moreover, it could very well be that resentments toward diversity are most intense from within the anti-capitalist intellectual classes, even though the totalistic nature of multiculturalism and diversity rhetoric, which the intellectuals themselves have created, represses such resentments. It is evident that those to the right of the political spectrum resent diversity and affirmative action, very often ignoring the hidden bases of their own privilege within supposedly meritocratic systems. But if Nozick is correct about the generalized resentment by intellectuals of successful people who "aren't as smart as them", this resentment must surely be intensified by the presence of new classes and groups of victims that are being advantaged by capitalist societies mainly on the grounds of who they are rather than what they have done. Finding out the extent of such resentment poses a very difficult ethnographic challenge, since the disjuncture between real feelings and adherence to ideologically correct behaviors is quite vast and the former lie deeply hidden beneath the latter.

Nozick does suggest that those who are actually diverse in intellectual settings may have fewer resentments than those who are the traditional bearers of anti-capitalist sentiment. He notes that women, for instance, with newfound mobility, enjoy the liberating experience of capitalism, which empowers them in a patriarchal society. While many left-liberal intellectual women might despise, say, Sarah Palin, who is not only not an intellectual, but strategically deploys anti-intellectualism in her politics, there still might be among them a sense of vicarious satisfaction in Palin's often victorious battles with traditional, patriarchal men. Extrapolating on this idea, when members of minority groups begin to achieve mobility through university education, they do not adopt the anti-capitalism of their professors from the 1960s who are still waging overt and covert wars against capitalism. They actually embrace capitalism, and understand that they do not have the luxury of being against it when they were for so long involuntarily excluded from it. Only a small minority of empowered minorities turn to the transgressive new disciplines such as women's studies and Africana studies and queer theory, in which tired old ideologies are dressed up in new multicultural clothing, and where students can be allowed to indulge in any ideological fantasy without the inconveniences or limitations of a rational epistemology.

The way I have discussed them, it would appear that anticapitalism as a thought-style is something that would endure simply by virtue of the fact that classes of intellectuals and capitalism will continue to exist in tension with each other. The anti-capitalist mentality has existed for quite some time and takes different epochal forms. One would be safe in predicting its existence over the longue duree. The fate of anti-capitalism as a thought-style - and here is where Feuer 
is instructive - will depend fundamentally on generational mechanisms and dynamics. The leaders of the class of radical intellectuals who took power in the academy will pass away. The New Left is very old for the younger generation of students; the Ulricke Meinhof who is the hero of literary theory, but who advocated and practiced the murder of the "bourgeoisie", is most likely unknown to most modern day students. Professors who try to instill the habitus of anti-capitalism in students by dressing it up in new forms, such as the critique of "neoliberalism" and "globalization", will run up against new generations who read Jagwash Bhagwati's defenses of globalization rather than Noam Chomsky's tired jeremiads against America and capitalism.

Younger generations have seen many of the pathologies of the 1960s in their own parents, and, if Feuer is correct in his theory of the conflict of generations, young people whose parents were anti-capitalists would be disposed to support capitalism in collective acts of generational rebellion. Members of younger generations are intimately tied to capitalism through technology. They understand that the opportunities for anti-capitalists are limited to low-paying, marginal jobs, which would make them even more resentful of capitalism than they are disposed to be by virtue of their socialization experiences. During their four years of vastly expensive liminality, their professors will offer them radical visions and attempt to reproduce themselves. They will have some luck in doing so, as students flock to courses where they can display a dialectical adolescent temperament against the establishment and for change (without any real sense of substance of such change). Occupy Wall Street can be something one does for a month or so in order to display the right attitude while waiting for a proper insertion point into the capitalist system down the road. Adolescent rites of passage fade into adulthood, the capitalist world beckons, and the future probably holds more of a possibility of what the great socialist Michael Harrington once called "embourgeoisification" than any kind of class war against the bourgeoisie, even though the current president of the United States depends on the rhetoric of class warfare for his political power. Young people in 2011 are signaling this in turning away from Barack Obama, even as he tries to reproduce the leftist ideologies of the past, which have always been so appealing to the young, but which he himself was too young to have experienced. The face of a future multicultural capitalist society looks more like Bobby Jindal or Marco Rubio than it does Stokely Carmichael or Angela Davis.

Thomas Cushman is the Deffenbaugh de Hoyos Carlson Professor in the Social Sciences and Professor of Sociology at Wellesley College. This article was written for a conference co-sponsored by the Manhat$\tan$ Institute and Society. Grateful acknowledgement is given to the Marilyn G. Fedak Capitalism Project for its support. 